\title{
IAMJ
}

INTERNATIONAL AYURVEDIC MEDICAL JOURNAL

\section{A NOBEL APPROACH OF DIABETIC NEUROPATHY \& ITS MANAGEMENT THROUGH AYURVEDA}

\author{
Rahul Parihar ${ }^{1}$, PratyushSharma ${ }^{2}$, A. K. Pandey ${ }^{3}$ \\ ${ }^{1}$ Ex JR, ${ }^{2}$ JR-3 ${ }^{\text {rd } 3}$ Associate Professor, Department of Kayachikitsa, Institute of Medical Sciences, Banaras Hindu \\ University, Varanasi, UP, India
}

Corresponding Author: rahul.parihar.ayu@gmail.com

\section{https://doi.org/10.46607/iamj09p5052021}

(Published online: July 2021)

Open Access

(C) International Ayurvedic Medical Journal, India 2021

Article Received: 01/07/2021 - Peer Reviewed: 09/07/2021 - Accepted for Publication: 10/07/2021

\section{Check for updates}

\begin{abstract}
Diabetes mellitus vis a vis Madhumeha is a multi-factorial metabolic disorder of the $21^{\text {st }}$ century. It is caused by an absolute or a relative lack of insulin. Its manifestations include hyperglycemia, other metabolic derangements, and long-term damage to blood vessels, eyes, nerves, kidneys, and the heart. It is a leading cause of cardiac death, nonfatal MI, heart failure and stroke. It is also the most common cause of adult blindness, end-stage renal disease, non-traumatic leg amputation and neuropathy. Diabetes mellitus is one of the oldest diseases recognized since antiquity. It is amazing that 7 century B.C. Ayurvedic texts like Charaka and Sushruta Samhita have been described high caloric diet and sedentary habits as an important causative factor of Apathyanitmittaja Prameha and genetic/hereditary factors described as Sahaja Prameha. Besides this, more profound Ayurveda have been mentioned different complications of Madhumeha. These two types of diabetics have been described to be treated on two different lines of management. Its aetiopathogenesis, clinical presentation, complications as well as treatment modalities, appear well comparable to the latest knowledge of conventional medicine. Thus, the present concept will be providing a new outlook about the understanding of aetiopathogenesis and as well management of Diabetic neuropathy.
\end{abstract}

Keywords: Ayurveda, Preameha, Madhumeha, Diabetes mellitus, diabetic neuropathy 


\section{INTRODUCTION}

Diabetes mellitus is a multifactorial metabolic disorder affecting millions of people all over the world. It is one of the most important medical problems of today because worldwide $>246$ million people suffer from diabetes mellitus all over the world. By 2025 this figure could be expected to be 380 million. It is estimated that every year a further 7 million people develop diabetes. India has been projected by $\mathrm{WHO}$ as the country with the fastestgrowing population of diabetic patients. Increasing urbanization, stress, obesity, reduced physical activity and pollution are together responsible to create this position. In 2007, the five countries with the largest numbers of people with diabetes are India (40.9 million), China (39.8 million), the United States (19.2 million), Russia (9.6 million) and Germany (7.4 million). WHO estimates that India may cross figures 57 million by $2025^{1,2,3}$. Diabetes as such does not kill the patient but it is the complications of diabetes that are responsible for mortality and morbidity. Diabetic neuropathy is one of the commonest complications associated with diabetes mellitus. Insulin is the mainstay of the treatment of both types of diabetes i.e. IDDM \& NIDDM. Insulin is a multifunctional protein hormone. It also has some side effects e.g., allergy and resistance. The insulin resistance is alone in the development of spontaneous antibodies directed against insulin receptors, thereby preventing the interaction of insulin with the insulin receptor ${ }^{4}$. The complications associated with diabetes are functionally silent for long period. By the time they manifest, the treatment becomes extremely tedious. The exact cause of diabetic neuropathy is still unknown. It is multifactorial. Poor glycemic control, long duration of diabetes, presence of cardiovascular diseases, hyperlipidemia, stress etc are to be considered the important risk factors for diabetic neuropathy. Advanced glycation end products (AGEs), sorbitol and diacylglycerol are the core factors for most diabetic complications including diabetic neuropathy. These factors appear as tissue toxins implicated in the pathogenesis of neuropathy, retinopathy, nephropathy etc. Recent research in the conventional system of medicine has revealed that the exact aetiopathogenesis of diabetes mellitus and its complications are still vague and it needs further studies. and In-spite of many advances in the and management of diabetes mellitus and its complications it remains unsatisfactory and challenging. This seeks great attention from the present-day practitioners and researchers to evaluate the present status of this chronic health hazard including the desire for a better understanding of the aetiopathogenesis, disease diathesis and its management ${ }^{5}$. It is amazing to note that the knowledge of diabetes mellitus was equally advanced in the ancient time of Ayurvedic classics. The Ayurvedic texts describe a high carbohydrate diet and sedentary habits as the important causative factors of Apathyaja Prameha (type-2, DM) besides hereditary and genetic factors described as Sahaja Prameha (type-1, DM). Besides this, diabetics are also categorised into two groups in terms of constitution and body weight vizI. Krisha Pramehee or thin diabetics and Sthoola Pramehee or obese diabetics. These two types of diabetics have been described to be treated on two different lines of management. This insight of categorizing into genetic and acquired and further as thin and obese is outstandingly scientific, comparable to the latest development in this field ${ }^{6,7}$.

\section{Concepts of Diabetes mellitus in Ayurveda}

Diabetes mellitus vis a vis Madhumeha has been a clinically known disease entity since antiquity. The first recognized written text of human civilization i.e., Rig-Veda (C 1500, BC) contains hymns that include a detailed description of various medical conditions including diabetes. In classical texts of Ayurveda, diabetes mellitus is mentioned as a subtype of Prameha, Mootratipravriittaja Vikara and as a complication of Prameha. While Shusruta has been described as Madhumeha as a disease separately. Charaka has described Prameha as Anushangi Vyadhi. Chakrapanidutta has explained that Anushangi means Punarbhavi i.e., the disease which is very difficult to be the cure. The ancient Acharyas of Ayurveda, vizCharaka(C 600, BC) and Sushruta (C 500, BC) have 
described the detailed account of this disease. All Ayurvedic classics have described in detail the aetiopathogenesis, symptomatology, classification, complication, prognosis, and management of diabetes vis a vis Madhumeha (presence of sugar in urine and body also). It is mentioned as a Maharoga in the classical text of Ayurveda because it affects all parts of the body and every cell of human physiology $y^{8,9}$. The ancient Indian physicians have not only described the sweetness of urine as one of the major symptoms but also the relationship of the disease with disturbance of the five sheaths of life, i.e.-

1- Annamaya kosha: sheath of food (Physical dimension).

2- Pranamaya kosha: sheath of energy (Energetic dimension).

3- Manomaya kosha: sheath of mind (Mental dimension).

4- Vijnanamaya kosha: sheath of intellect (Intellectual dimension).

5- Anandamaya kosha: sheath of bliss (Spiritual dimension).

According to Ayurveda diabetes mellitus may be of two types, viz-

i. Sahaja (genetic): Occurring in the younger age group from the very beginning of life. This concept is comparable to the modern concept of insulindependent diabetes or juvenile diabetes.

ii. Apathyaja (acquired due to faulty lifestyle): Occurring in middle age obese people. This concept is comparable to the maturity-onset, non-insulindependent as well as insulin resistance type of diabetes mellitus ${ }^{10}$. The ancient concept of Bijadosha (gene defects) is strikingly comparable to present-day knowledge and testifies that the ancients could detect genetic factors involved in the causation of diabetes mellitus (S.S.Ci-11/3). A Sahaja vikara is manifested due to certain defects in the Beeja, Beejabhaga, Beejabhaagavayava. In this connection, Neelakanthadatt clearly states that diabetes mellitus is not since birth, but it develops at a later stage associated with dietetic indiscretions. Sushruta rightly said that Ksetra, Ambu, Bija and Ritu are the four factors that are to be kept in mind while describing the genetic involvement. Besides this Charaka has also included the psychological factors (worry, anger, anxiety, and stress) in the aetiology of diabetes mellitus in susceptible individuals ${ }^{7,8}$.

Vagbhata seems to have paid much attention to diagnosing the disease in its early stage explaining the following in his treatise Rasaratna samucchaya.

1- Asvasthyam Sarva gatreshu - a persisting \& vague uneasiness in the body. This condition is

more supported by Susruta as follows- Gamanat sthanam- prefers staying to walk., Sthanat asanamprefers sitting to stand., Asanat shayanam- prefers lying to sit. Shayanat svapnam- prefers sleeping to lying down.

2- Shosha /Asyashosha- a feeling of dryness/drought in the body.

3- Tapo angah- a burning sensation in the body.

4- Bahumootrata. Frequency of urination.

5- Karshyam- Emaciation ${ }^{11}$.

However, when the disease is well established and neglected apart from the above features, urinary changes become more distinct namelyPrabhootaavilamootrata (A.H.Ci.10/7).

1. Prabhootamootrata - excessive urination.

2. Avilamootrata-- turbidity in urine.

The former is more akin to impairment of carbohydrate, protein and fat metabolism and the latter one is to urinary tract pathology which occurs in a variety of urinary as well as extra urinary tract pathology. The following features are specific to diabetes mellitus;-

- Urine is astringent, sweet, pale and ununctuous (C.Ci.4/44)

- Urine is just like Ksaudra (honey) in taste and colour- Madhviva mehati (S.Ni.6/14).

- The whole body becomes sweetenedMadhuryacha tanoratah (A.H.Ni.10/18-27).

- Ojas (immune strength) is diminished, the person becomes timid, week, worried,

- having disordered of senses, loss of lustre, neurasthenic, dry and emaciated (C.Su.17/43).

- Diabetic patients prefer a sedentary lifestyle. (S.Ni.6/28) $7,10,12,13$. 


\section{Ayurvedic Approach}

In the classical texts of Ayurveda, various complications (upadravas) of Madhumeha such as Trishna, Atisara, Jvara, Daha, Dourbalya, Arochaka, Pootimamsa (Gangrene), Pidaka, Hridgraha, Hrithshoola etc have been described. But the etiopathology of diabetic complications is not very clear in these texts. Thus, the present concept of diabetic complications will provide a new outlook about the understanding of etiopathogenesis as well as management ${ }^{8}, 14,15,16$. Apart from various etiological factors responsible for the causation of Prameha, the Ayurvedic texts include Agni (bio fire), Ama (unwanted, un-metabolized, toxic products etc.), Ojas (immune factors) and Medas (adipose tissue) as the major morbid factors. These two observations of the ancients again appear to be very scientific comparable with the modern trends of medical science of today. Because it is now well known that in terms of the resulting metabolic disorders, the hallmark of diabetes mellitus is the disorder of fat metabolism and ketosis. Similarly, it is also being gradually recognized that there is strong evidence of immune disorder and immunodeficiency in all diabetics. Possibly because of these factors, the propounders of Ayurveda considered Ojas as a Dushya of Prameha and Madhumeha was also termed as Ojomeha. Agni in the body is responsible for the digestion of food and the metabolism of the essence of food at different levels. When the Agni, i.e. - Jatharagni (gastrointestinal bio fires), Dhatvagni and Bhootagni (cellular bio fires) become weak, it leads to the formation of Ama, an unwanted byproduct at respective levels. This form of Ama has physical similarity to Medas. It impairs the function of Medoagni, resulting in qualitative and quantitative defects of Medas. This impaired form of Medas is known as Abadha Medas, i.e.-FFAs (a liquid form of Medas). Due to increased FFAs levels in serum, the glucose entry to the cells is hampered, resulting in insulin resistance and finally hyperglycemia (diabetes mellitus). thus, the involvement of Agni appears to be the initial pathological event in diabetes, which is pointed out by Vagbhata in Sutrasthana i.e.- "Rogah sarveapi mandeagnau" $"$.

Increased FFAs and sugar levels in the serum (away from the normal range) are also considered as Ama state. It tends to block the microchannels, create an antigenic reaction and if retained in the body act as an autotoxin i.e., directly destroy the body cells. Ama is predominantly associated with Dhatukshaya (degeneration of cells), Ojokshaya (diminished immune status) and Vataprakopa (an impaired neurohumoral mechanism). The Dhatukshaya due to the Vyadhi Svabhava itself can lead to Vata Vriddhi in the body, which in turn exacerbates the existing vitiated Vata dosha in the diabetics. A vicious cycle is set up, resulting in Ojokshaya and Dhatukshaya. This may lead to the process of neurodegeneration. Therefore, the manifestation of symptoms can be considered as below.

Vyana Vayu is mainly responsible for the coordinated action of all the body parts including the sensory and motor functions. Due to the Dhatukshaya, Ojokshaya and Vyadhisvabhava, it can lead to vitiating the Vyana $v a y u$. It has a directly or indirectly deleterious effect on Tarpaka kapha i.e. neuroprotective factor. Tarpaka kapha is mainly responsible for the performance of the neural function. It not only provides a nutritional supplement to the functioning neuron but also acts as a protective barrier against a variety of injurious agents $^{7,10}$. The deranged function of Tarpaka Kapha by Ama and vitiated Vata lead to impair the function of nerves in the general or nervous system. The sequence of pathological events in Ayurveda is as follows- 


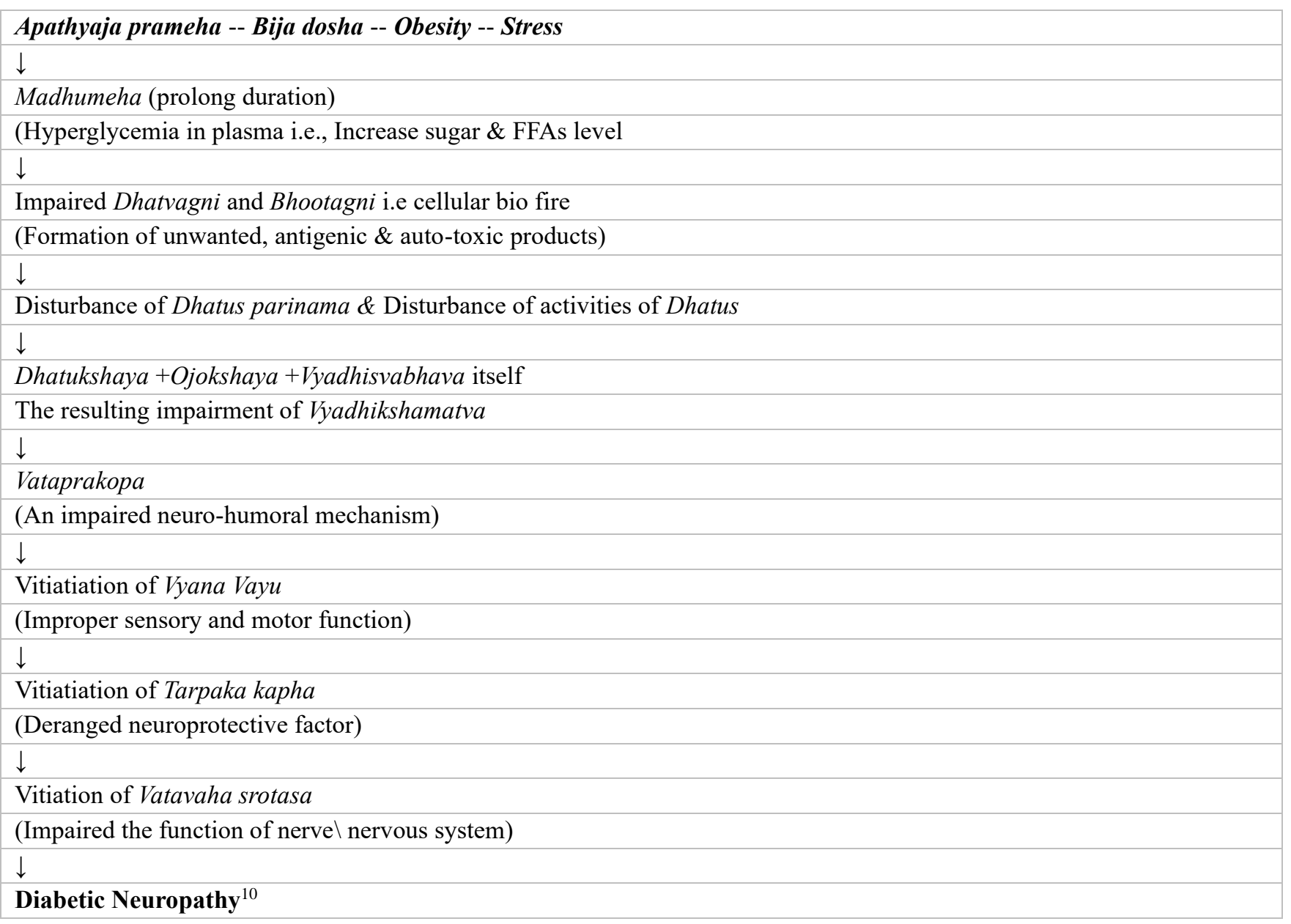

Ayurvedic Pathological component in diabetic neuropathy -

> Dosha-Tridosha (Specially Vyana Vata and Tarpaka kapha).

> Dooshya-Rasa, Rakta, Mamsa, Meda, Kleda, Majja, Oja, Shukra, Jala (specially Meda and Mamsa).

$>$ Status of Agni- Jatharagni Vriddhi due to increased function of Samana Vayu, this happens due to Srotavarodha. Functions of Dhatvagnis and Bhootagnis (specially Medoagni) are also deranged in diabetes

$>$ Site of Ama formation - At the level of Jatharagni, Dhatvagnis and Bhootagnis.

$>$ Involvement of Srotasa- Specially Rasavaha, Vatavaha, Mamsavaha, Medovaha, Mootravaha Srotasa

$>$ Srotodushti-Atipravritti and Sanga
> Adhishthana- Initially in Shakha and later in $\mathrm{Ko}$ shtha, Marma, Asthi and Sandhi

> Pratyatma Lakshana- Prabhootavilamootrata, Shuptata, Shoola Anganama etc

> Sancharasthana- Sarvanga Sharira via, Nadi, Sira, Dhamani, Rasayanee

$>$ Roga Marga-Abhyantara and Shakha Pradesh

$>$ Vyadhi Svabhava-Chirakari

> Sadhya - Asadhyata - Kaphaja-Sadhya, PittajaYapya, Vataja-Asadhya, 10

\section{Etiopathogenesis of diabetic neuropathy}

Conventional Approach

Diabetic microangiopathy is dysfunctional changes in microvascular beds in which endothelium and associated mural cells are progressively damaged, resulting in capillary occlusion, ischemia, and organ failure. Damage to the microvasculature in peripheral nerves is now becoming recognized as a major pathogenic factor in diabetic neuropathy. Diabetic 
neuropathy is one of the commonest complications of diabetes and is certainly one of the most distressing. All neuropathies are characterized by a progressive loss of nerve fibres. Animal and in vitro experiments have implicated a variety of enzymatic and nonenzymatic metabolic mechanisms in the initiation of glucose neurotoxicity. The metabolic initiators include non-enzymatic glycation of proteins, the subsequent chemical rearrangement yielding complex proteins called Advanced glycation end products (AGEs), Auto oxidation of glucose by increased Aldose reductase activity, leading to accumulation of sorbitol and fructose within the cell and activation of protein kinase C. Recently, AGEs have been increasingly implicated in the pathogenesis of diabetic microangiopathy. However, their role in diabetic nephropathy and retinopathy is still under intense investigation ${ }^{17,18,19.20,21}$. These mediators tend to interrupt the nerve blood flow, impaired neurotrophic support, altered protein $\backslash$ cell function $\backslash$ gene expressions and enhance the process of neural cell apoptosis.

\section{Clinical presentation}

1. Patients have a classical presentation likepolyuria, polydipsia, polyphagia, along with features of diabetic neuropathy such as-

2. Peripheral Neuropathy: Loss of senses or feeling of pain is first felt in the extremities, especially in the toes, feet and hands. It may also occur in the other ports of the body, the features are muscle weakness, numbness and pain.

3. Autonomic Neuropathy: It mainly affects the digestive system and the nerves that control blood pressure. This form of Neuropathy causes problems with the bladder, bowel, sexual response and perspiration etc.
4. Central Neuropathy: it may lead to neurological problems like dementia, cognitive impairment, depression, anxiety etc ${ }^{10,22,23}$.

\section{Diagnostic Approach of diabetic neuropathy:}

It is broadly divided into two categories-

1. Clinical diagnosis: It is mainly based on the classical symptoms of diabetes and symptoms related to diabetic neuropathy such as Polyuria, polydipsia, polyphagia, joint pain, muscle weakness, numbness \& pain in the extremities, impotency, incontinence of urine, banalities, fatigue, hypertension, cardiac pain, blurred vision, nephropathy, ulceration, dementia, cognitive impairment etc.

2. Laboratory diagnosis: The American Diabetes Association requires the presence of one of the following criteria for the diagnosis of diabetes (ADA-2006). Diabetes is diagnosed by measuring blood glucose levels. It is diagnosed in three ways, and each must be confirmed on a subsequent day. They are- Classical symptoms of diabetes + casual glucose concentration $\geq 200$ $\mathrm{mg} / \mathrm{dl}$.

Fasting plasma glucose $(\mathrm{FPG}) \geq 126 \mathrm{mg} / \mathrm{dl}$.

$>$ 2- Hour plasma glucose $(\mathrm{PPG}) \geq 200 \mathrm{mg} / \mathrm{dl}$ during an OGTT

* The fasting plasma glucose test is preferred because of administrative convenience, acceptability to the patients and lower cast. Fasting is defined as no caloric intake for at least 8 hours.

* 2-hour plasma glucose test requires the use of a glucose load containing $75 \mathrm{gm}$ glucose in water followed by plasma glucose measurement 2 hours later.

* Casual plasma glucose test should be performed any time of the day without regard to the last meal.

\begin{tabular}{|l|l|l|l|}
\hline Category & $\begin{array}{l}\text { Fasting plasma } \\
\text { glucose in } \mathbf{~ m g / d l ~}\end{array}$ & $\begin{array}{c}\text { 2-hour plasma } \\
\text { Glucose in } \mathbf{~ m g / d l}\end{array}$ & Casual plasma glucose in $\mathbf{m g} / \mathbf{d l}$ \\
\hline Normoglycemia & $<100$ & $<140$ & - \\
\hline IFG/IGT & $100-125$ & $140-199$ & - \\
\hline Diabetic range & $\geq 126$ & $\geq 200$ & $>200+$ classical Symptoms of diabetes \\
\hline
\end{tabular}

IFG- impaired fasting glucose OGTT- oral glucose tolerance test. IGT- - impaired glucose tolerance PPGpostprandial glucose. 
3. Glycosylated haemoglobin (HbA1c) test: It is an important glycemic parameter to assess the severity of disease in clinical practice. By this test plasma glucose can also be calculated. The expected values of HbA1c $\%$ are given in the table.

\begin{tabular}{|l|l|}
\hline Category & Expected values in \% \\
\hline Nondiabetic & $4.5-<7$ \\
\hline Good control & $7-<9$ \\
\hline Fair control & $9-<10$ \\
\hline Poor control & $\geq 10$ \\
\hline
\end{tabular}

$<1 \%$ rise in the $\mathrm{HbAl}=1.7 \mathrm{mmole} / 1(30 \mathrm{mg} / \mathrm{dl})$ increase in the mean glucose load $>$

4. Diagnosis of Neuropathy: If neuropathy is suspected after preliminary examination, it is also important to perform more extensive tests to determine the degree of the problem. This may include Comprehensive foot examination to assess the circulation and sensation., Check superficial and deep reflexes., Test the ability to Sense vibrations in the foot., Nerve conduction study., Electromyography etc., C- reactive protein.

Other laboratory tests in elderly diabetics: In symptomatic individuals following laboratory tests are routinely performed to assess the therapeutic response and other associated complications, vizBlood for - TLC, DLC, ESR, $\mathrm{Hb} \%$., Urine for glucose, protein, ketone bodies and microscopic examination for the presence of pus cells., Blood sugar- fasting and PP., Glycosylated $\mathrm{Hb}-(\mathrm{HbA} 1 \mathrm{c}$, it is $<7 \%$ in normal individuals) for assessing the degree of glycemic control \& monitoring treatment. Blood urea, Serum creatinine, Lipid profile, Serum cholesterol, CRP, NCV etc en, $25^{25}$

\section{Management of Diabetic Neuropathy}

No doubt modern medicine may have found a way to bring the cases of diabetes mellitus and its complications under control to some extent, yet the effort cannot be considered as final. It is because of the danger of complications such as drug resistance, hypersensitivity and antagonist formation with insulin, drug intolerance, fear of hypo and hyperglycemic episode with Sulphonylureas. This seeks great attention from the present-day practitioners and researchers to evaluate the present status of this chronic health hazard and to evolve newer strategies in their management ${ }^{7,10}$. In this regard, Ayurvedic drugs not only have Pramehaghna ie.- anti-diabetic property but also have Rasayana effect i.e. improve nutritional pool, Ojovardhaka effect i.e. immune enhancer, Jivaneeya effect i.e. longevity enhancer and Balya effect i.e. vitalizer. By these properties, Ayurvedic drugs alone or in combination with modern medicine, can reduce the insulin as well as oral hypoglycemic drug requirement, prevent or delay the long-term complications, and maintain overall health in elderly diabetics $^{12,13}$.

The first and foremost principle of prevention, as well as the management of any disease, is to protect oneself from the causative factors i.e. - Sankshepatah kriya yoga nidanam parivarjanam. (S.U.1/25).

Charaka has divided the diabetics into two groups, i.e. Sthulapramehi (obese diabetics) and Krishapramehi (lean and thin diabetics) based on vitality, constitution and aetiology of the disease. This warrants different lines of management for the two types of diabetics ${ }^{8,15}$, 16. Santarpana measures are In Krisha Madhumehi i.e. - lean and thin diabetics., In Vataja Madhumehi i.e. - patients of type-I diabetes., In Vataja Madhumehi associated with complications Apatarpana measures, Kaphaja and Pittaja Madhumehi i.e. - patients of typeII diabetes.

Patients of type-II diabetes associated with complications. Besides these measures, Charaka has been advocated pacificatory measures such as decoctive preparations, powder of barley (Yava), and quantitative as well as qualitative light diet in the management of diabetic patients who are not suitable 
to Sodhana measures. At present, the goal of diabetic treatment is not only to correct the hyperglycemia but also to improve the quality of life as well as the immune status of the patients besides attempts to prevent and manage the complications. At this juncture the proper management of diabetes and its related complications may be envisaged as below: The treatments of Diabetic Mellitus vis-à-vis Madhumeha as mentioned in Ayurvedic classics can be broadly divided into four groups-

1. Nidana Parivarjana- Avoidance of etiological factors, i.e.-faulty lifestyle, faulty dietary habits, mental stress, day sleep and awakening at night.

2. Ahara-Diet is an important regimen for the control of diabetes mellitus. It is an important measure for obese diabetics. The role of diet in the management of diabetes mellitus has the same importance as it was thousands of years back. Katu, Tikta, Kashaya Rasa, Ushna, Laghu, Rooksha properties of food are prescribed in diabetes. Dieting is an important measure for obese diabetics and a special dietary regimen is to be planned to lean and thin diabetics during management.

- The food which is enriched with alcohol, milk, oil, Ghee, flour, syrup, and meat of the animals which are residing in water or near water should be avoided (S.S.Chi; 11: 5).

- Foods like Yava (barley), bitter, pungent, and astringent vegetables, the meat of animals residing in hot climates and pulses/cereals like-Shyamaka. Kodrava, Uddalaka, Godhooma, and Kulatthaare to be taken by all patients of diabetes mellitus (Shodhala K.C. Khanda; 30: 41-42).

3. Vihara- The role of exercise has been emphasized by Acharya Sushruta in the management of poor and rich diabetic patients.

- For poor patients- there is an indication of light exercise and earn his living by begging.

- For rich patients - there is an indication of heavy exercise and earn their living by begging.

Recent evidence shows that exercise, meditative Asanas \& lifestyle management not only improve hyperglycemia but are also believed to improve pancreatic and liver functions.
4. Aushadha/Ayurvedic formulations- In Ayurvedic classics several herbal and herbo- mineral drugs are advocated for the treatment of Prameha in general. Drugs having Katu (pungent), Tikta (bitter) and Kashaya (astringent) Rasa are indicated in all types of Prameha, i.e. diabetes and its related complications.

- Herbal drugs:viz-Vijayasara, Nisha, Amalaki, Mamajjaka, Jamboo, Bilvapatra, Tejapatra, Nimba, Karvellaka, Pippali. Guduchi, Khadira, Kramuka, Bhoomyamalaki, etc

- Mineral drugs: viz-Shilajatu, Svarnamaksheeka, Shivagutika, Trivanga Bhasma, Naga Bhasma etc.

- Herbo-mineral preparation:

* Classical: Basantkusamakararasa, Pramehantaka Vati, Chandraprabha Vati etc.

* Neo-formulations. Hayponid, Amaree plus granules and tablet, Diabecon etc.

5. Promotion of Ojas or immune status- drugs having Rasayana, Jivaniya and Pramehaghna properties e.g.- Nisha, Amalaki, Shilajatu, Svarnamakshika etc.

6. Promotion Agni, i.e. bio fire- drugs which act at the level of Agni e.g.- Pippali, Maricha, Chitraka, Shunthi, Bhallatak etc.

7. Avoidance of mental stress by practicing meditative Asanas and Pranayam under trained Yoga experts.

In the Ayurvedic classics, various preparations have been advocated for the treatment of diabetes mellitus and its related complications. Based on the physical strength of the patient and strength of the disease following drugs are commonly prescribed as a single drug or in combinations or with compound drugs in Ayurvedic practice for the treatment of diabetes mellitus and diabetic neuropathy.

\section{Single drugs preparations}

Amalia Churna- 8 gms in two divided doses., Haridra Churna- 8 gms in two divided doses., Mamajjaka Churna- 6 gms in two divided doses., Shuddha Shilajit- $1 \mathrm{gm}$ in two divided doses, Vijayasara Churna- 4-6 gms in two divided doses., Karvellaka Svarasa- 20-40 $\mathrm{ml}$ in two divided doses., Jamboobeeja Churna - 6-12 gms in two divided 
doses., Guduchi Svarasa- 10 to $20 \mathrm{ml}$ twice a day.

\section{Compound drug preparations}

Basantakusamakara rasa-250 $\mathrm{mg}$ in two divided doses., Pramehantaka vati- $500 \mathrm{mg}$ in two divided doses., Chandraprabhavati-1 gm in two divided doses., Trivanga Bhasma- $500 \mathrm{mg}$ in two divided doses. Madhookasava- $40 \mathrm{ml}$ in two divided doses with an equal quantity of water.

\section{In the case of diabetic neuropathy}

The following drugs are found very effective in the management of all types of diabetic neuropathies. Ashvagandha Choorna/Tab- 6 gms/4 Tab in two divided doses. Dashamooladi taila and Prasarani taila - for local application. Dashmula Ghana Vati$600 \mathrm{mg}$ in two divided doses. Vasanta Kusumakar Rasa- $250 \mathrm{mg}$ in two divided doses. Yogendra Rasa$200 \mathrm{mg}$ in two divided doses. Shilajithvadi Louha$500 \mathrm{mg}$ in two divided doses. Prava, Mukta, and Shukti Bhasma- $500 \mathrm{mg}$ in two divided doses. Shiva Gutika- $500 \mathrm{mg}$ in two divided doses 7,10,8,15,16.

\section{CONCLUSION}

We finally conclude that Prameha/ Madhumeha of Ayurveda is a metabolic disorder and resembles greatly the known contemporary concept of diabetes mellitus. As per Ayurveda, it is presumed that the disease diabetes itself and its complications emerge as simultaneously. Further, the duration of diabetes and its uncontrolled condition may lead to developing diabetic complications including neuropathies. The exact pathogenesis and management of diabetes and diabetic neuropathy is not clearly understood to date. Hence the above said Ayurvedic concepts of diabetic neuropathy can be taken as leads to the understanding of pathogenesis as well as the management of diabetes for contemporary use today.

\section{REFERENCES}

1. Beckman JA, Creager MA, Libby P. Diabetes and atherosclerosis: epidemiology, pathophysiology, and management. JAMA. 2002;287: 2570-81.

2. International Diabetes Federation. IDF diabetes atlas. 8th ed. Brussels: International Diabetes Federation; 2017. http://www.diabetesatlas.org. Accessed on 17/03/2020.
3. Alberti KGMM: Lifestyle diseases in developing world in British Medical Journal, vol. 309, No. 6957. British Med. Asso. Tavistock Square, London. 1994.

4. Jaspreet Singh, A.K.Pandey \& R.H Singh. PreventionPotential in Type 2 Diabetes Mellitus. Annals of Ayurvedic Medicine (AAM), ISSN: p-2277-4092, e-23476923, Vol. 3 (1): pages 62-63, January 2014.

5. Anurag Singh, Ragni Srivastava, Ajai Kumar Pandey. Effect of the seeds of Terminalia chebula on blood serum, lipid profile and urine parameters in STZ induced diabetic rats. Journal of Pharmacognosy and Phytochemistry, ISSN: e-2278-4136 \& p-2349-8234, Vol-7, Issue-2: 01-05, February 2018.

6. Anurga Singh, Ragni Srivastava, Ajai Kr Pandey. Protective Role of Terminalia chebula in Streptozotocininduced Diabetic Mice for Wound Healing Activity. British Journal of Medicine \& Medical Research, ISSN: 2231-061, 22(2): pages-1-8, 8th July 2017.

7. Pandey A. K. (2000): A study of Immune status in patients of Diabetes mellitus with the role of Pancakarma and Naimittika Rasayana drugs, MD (Ay) Kayachikitsa thesis, IMS, BHU, Varanasi, UP, India.

8. Charaka Samhita with Ayurvedadipika commentary of Cakrapani data, Ed.Yadava ji Trikam ji Acharya, Nirnaya Sagar Press, Bombay -1941.

9. Ajai Kumar Pandey: "A Textbook of Kaya- Chikitsa" Vol- III in Hindi, 1st Edition 2019 in Hindi, ISBN: 97881-942481-1-8; Published by Chaukhamba Publications, 4262/3, Ansari Road, Darya Ganj, New Delhi110002 , India.

10. Ajai Kumar Pandey (2012): A clinical study on certain diabetic complications under the influence of Naimittika Rasayana therapy (with special reference to Nisha-amalaki \& Shilajatu), PhD Kayachikitsa thesis, IMS, BHU, Varanasi.

11. Sri Ambikadatta Sastri (2016). Rasa Ratna Samucchaya of Vagbhata, Published by Chaukhambha publications, New Delhi, India.

12. Anshu Gangwar, A. K. Pandey. Effect of Darvyadi Ghana vati in prediabetes: A case study. Bhugol Swadesh Charcha (Multidisciplinary International Journal), Vol.16, Special Issue 1, January 2020, page no. 1-4.

13. Chaudhary Umesh \& Pandey A. K.(2013): A Clinical assessment of the role of panchakarma therapy in the cases of young prediabetes, International journal of general medicine and pharmacy (IJGMP), vol. 2, Issue 1, Feb 2013, 15-24.

14. Ajai Kumar Pandey: "A Textbook of Kaya- Chikitsa" Vol-II in Hindi, 1st Edition 2019 in Hindi, ISBN: 978- 
81-938519-6-8; Published by Chaukhamba Publications, 4262/3, Ansari Road, Darya Ganj, New Delhi110002 , India.

15. Ashtanga Hrdaya, $11^{\text {th }}$ Edn. (1993), Comm. Atrideva Gupta, Pub.- Chaukhambha Sanskrit Sansthan, Varanasi.

16. Ashtanga Sangraha of Vrddha Vagbhata, Ed. Anant Damodar Athawale, Pub.- Mahesh Anant Athawale, Srimad Atreya Prakashan.

17. Banerji, M.A. Lebovitz, H.E.: Insulin Sensitivity and Insulin resistant variant in NIDDM. Diabetes, 1989, 38-784.

18. CotterM.A., Ekberg K., Wahren J., Cameron N.E.: Effects of proinsulin $\mathrm{C}$ - peptide in experimental diabetic neuropathy: vascular actions and modulation by nitric oxide synthase inhibition. Diabetes 52:1812-1817, 2003.

19. Dyck PJ, Hansen S, Karnes J, O'Brien P, Yasuda H, Windebank A, Zimmerman B. Capillary number and percentage closed in human diabetic sural nerve. Proc Natl Acad Sci USA 1985; 82: 2513-7.

20. McRobert EA, et al: The Amino-terminal domains of the ezrin, radixin and moesin proteins bind advanced glycation end products, an interaction that may play a role in the development of diabetic complications. J Biol Chem 278:25783-25789, 2003.

21. Seftel AD, Vaziri ND, Ni Z, Razmjouei K, Fogarty J, Hampel $\mathrm{N}$ et al. Advanced glycation end products in the human penis: elevation in diabetic tissue, site of deposition, and possible effect through iNOS or eNOS. Urology 1997; 50: 1016-26.I

22. American diabetic association: Treatment target for diabetes. Diabetes care 20007; 30 (Suppl. I): S 4- S41,

23. American diabetic association: Standards of medical care in diabetes. Diabetes care 2007; 30 (Suppl. I): S 4- S41.

24. Blaum CS. Management of diabetes mellitus in older adults: are national guidelines appropriate? J Am Geriatr Soc. 2002; 50:581-583.

25. Brown AF, Mangione CM, Saliba D, et al. California Healthcare Foundation/American Geriatrics Society Panel on Improving Care for Elders with Diabetes. Guidelines for improving the care of the older person with diabetes mellitus. J Am Geriatr Soc. 2003; 51(5 Suppl Guidelines): S265-S280.

\section{Source of Support: Nil Conflict of Interest: None Declared}

How to cite this URL: Rahul Parihar et al: A Nobel Approach Of Diabetic Neuropathy \& Its Management Through Ayurveda. International Ayurvedic Medical Journal \{online\} 2021 \{cited July, 2021\} Available from: http://www.iamj.in/posts/images/upload/3012_3021.pdf 